\title{
PENGARUH STRATEGI PEMBELAJARAN PEER LESSON TERHADAP HASIL BELAJAR IPA TERPADU SISWA KELAS VIII SMP NEGERI 6 KOTA BIMA TAHUN PELAJARAN 2018/2019
}

\author{
Fitrah, Erni Suryani, Anita Rahmawati \\ Pendidikan Biologi, Sekolah Tinggi Keguruan dan Ilmu Pendidikan (STKIP) Bima
}

\begin{abstract}
ABSTRAK
Penelitian ini bertujuan untuk Mengetahui pengaruh strategi Pembelajaran Peer Lesson terhadap hasil belajar IPA Terpadu siswa kelas VIII SMP Negeri 6 Kota Bima. Jenis penelitian yang digunakan adalah Quasi eksperimen dengan desain Posttest-Only Control Group Design. Populasi yang digunakan adalah semua kelas VIII SMP Negeri 6 Kota Bima. Yang terdiri atas dua kelas. Teknik pengambilan sampel menggunakan Simple Random Sampling yaitu memilih 29 orang dari masing-masing kelas dengan melihat nilai awal siswa kemudian menjadikan satu kelas sebagai kelas eksperimen dan satu kelas sebagai kelas kontrol. Instrumen yang digunakan dalam penelitian ini adalah tes hasil belajar, dan lembar observasi. Teknik analisis data yang digunakan menunjukkan bahwa nilai rata-rata hasil belajar siswa untuk kelas eksperimen yang diajar menggunakan strategi pembelajaran Peer Lesson sebesar 69,31 sedangkan untuk kelas kontrol yang tidak diajar menggunakan strategi pembelajaran Peer Lesson sebesar 52,06.

Hasil penelitian menunjukkan uji hipotesis diperoleh $t_{\text {hitung }}=4,758>t_{\text {tabel }}=2,003$. Karena nilai $t_{\text {hitung }}>t_{\text {tabel }}$ maka Ha diterima dan H0 ditolak. Dengan demikian dapat disimpulkan bahwa terdapat perbedaan hasil belajar yang signifikan antara siswa yang diajar dengan Strategi pembelajaran Peer Lesson dengan siswa yang tidak diajar dengan strategi pembelajaran Peer Lesson pada kelas VIII SMP Negeri 6 Kota Bima.
\end{abstract}

Kata kunci: Strategi Peer Lesson, Hasil Belajar. 


\section{PENDAHULUAN}

Pendidikan merupakan hal utama dan menjadi salah satu faktor terpenting dalam menjalani hidup bermasyarakat, berbangsa dan bernegara. Sebab tanpa pendidikan, manusia tidak akan pernah mengubah strata sosialnya untuk menjadi lebih baik. Disamping itu pendidikan juga ditujukan mampu memberikan peningkatan pada aspek penting yang melekat pada manusia yaitu aspek kognitif. Oleh karena itu dibutuhkan strategi pembelajaran yang mampu memberikan kemudahan bagi para peserta didik dalam memahami ilmu pengetahuan yang mereka pelajari. Strategi pembelajaran merupakan rencana tindakan termasuk penggunaan metode dan pemanfaatan berbagai sumber daya dalam pembelajaran. Strategi pembelajaran menentukan pendekatan yang dipilih guru untuk mencapai tujuan pembelajaran. Strategi pembelajaran merupakan suatu konsep yang dipilih untuk mencapai tujuan pembelajaran secara efektif dan efesien sehingga guru perlu mempertimbangkan output dan dampak pembelajaran dalam memilih suatu strategi (Abdullah, 2013).

Strategi pembelajaran Peer Lesson merupakan salah satu strategi pembelajaran aktif yang dirancang untuk mengaktifkan peserta didik sehingga peserta didik tidak belajar secara monoton. Peer Lesson sendiri berasal dari kata Peer dan Lesson. Peer mempunyai arti teman sebaya dan Lesson mempunyai arti pelajaran. Strategi pembelajaran Peer Lesson merupakan salah satu dari pembelajaran model Peer Teaching. Strategi ini mengajarkan peserta didik untuk belajar aktif. Melalui pembelajaran aktif berarti peserta didik mendominasi proses pembelajaran. Strategi pembelajaran Peer Lesson baik digunakan untuk menggairahkan kemauan peserta didik mengajarkan materi kepada temannya. Jika selama ini ada pameo yang mengatakan bahwa metode belajar yang paling baik adalah dengan mengajarkan kepada orang lain. Maka strategi ini akan sangat membantu peserta didik didalam mengajarkan materi kepada teman-teman sekelasnya (Zaini, 2008).

Menurut (Silberman, 2008) "Peer Lesson adalah strategi yang mengembangkan kemauan peserta didik mengajarkan materi dalam kelas yang menempatkan seluruh tanggung jawab untuk mengajar para peserta didik sebagai anggota kelas". Ketika kegiatan belajar sifatnya pasif, peserta didik mengikuti pelajaran tanpa rasa keingintahuan, tanpa mengajukan pertanyaan, dan tanpa minat terhadap hasilnya (kecuali, barangkali, nilai yang akan dia peroleh). Ketika kegiatan belajar bersifat aktif, peserta didik akan mengupayakan sesuatu. Dia menginginkan jawaban atas sebuah pertanyaan, membutuhkan informasi untuk memecahkan masalah, atau mencari cara untuk mengerjakan tugas. Strategi Peer Lesson (pelajaran teman sebaya) adalah sebuah strategi yang mengembangkan peer teaching dalam 
kelas yang menempatkan seluruh tanggung jawab pembelajaran kepada seluruh anggota kelas".

Salah satu strategi pembelajaran yang dapat meningkatkan keaktifan para peserta didik adalah strategi pembelajaran Peer Lesson. Menurut (Dwijayanti, 2016) menjelaskan bahwa strategi pembelajaran Peer Lesson memberikan kesempatan dimana peserta didik yang kurang mampu dibantu oleh peserta didik yang lebih mampu dalam menyerap materi pelajaran. Satu teman membimbing satu teman atau satu teman membimbing beberapa teman dalam kelompok, sehingga peserta didik yang malu-malu bertanya kepada guru dapat bertanya kepada temannya yang sudah menguasai materi tersebut. Beberapa ahli percaya bahwa satu mata pelajaran benar-benar dikuasai hanya apabila seseorang peserta didik mampu mengajarkan kepada peserta didik lainnya dan juga fakta di lapangan bahwa tingkat emosi antara peserta didik dengan guru berbeda, anak yang belajar dari temannya memiliki status dan tingkat umur yang cenderung sama maka dia tidak akan merasa terpaksa dalam menanggapi ide-ide ataupun sikap dari gurunya, melalui strategi pembelajaran Peer Lesson juga peserta didik akan lebih bebas dalam menyampaikan pendapatnya dan dapat lebih aktif dalam pembelajaran, sehingga berpengaruh terhadap hasil belajar peserta didik, untuk itu perlu adanya teman sebagai pembantu dalam belajar. Peran teman juga dapat mendukung adanya suatu motivasi tersendiri bagi anak.

Kondisi awal yang menjadi sebab dilakukannya penelitian ini adalah terdapat masalah pada saat pembelajaran berlangsung yakni, (1) Pembelajaran terkesan monoton, (2) Hasil belajar peserta didik rendah. Oleh karena itu, peneliti melakukan perbaikan dengan menerapkan strategi pembelajaran Peer Lesson. Dengan penerapan strategi Peer Lesson, diharapkan mampu menjadikan peserta didik lebih termotivasi untuk aktif dalam pembelajaran, sehinga dapat meningkatkan hasil belajarnya.

Penelitian yang dilakukan oleh seorang peneliti haruslah memiliki keterkaitan dengan penelitian lain yang telah dilakukan sebelumnya. Penelitian yang relevan dengan penelitian ini antara lain: Veronica Laelatul Fikriyah, 2013. Dalam penelitiannya yang Berjudul "Efektifitas Strategi Peer Lesson dalam Pembelajaran Bahasa Arab Siswa Kelas VIII MTsN Lab UIN Yogyakarta". Penelitian ini bertujuan untuk mengetahui efektif tidaknya penggunaan strategi Peer Lesson dalam pembelajaran Bahasa Arab dilihat dari kelas kontrol (kelas yang tidak menggunakan strategi Peer Lesson) dan kelas eksperimen (kelas yang menggunakan strategi Peer Lesson). Hasil penelitian ini menunjukkan bahwa penggunaan strategi Peer Lesson sangat efektif dalam pembelajaran Bahasa Arab, hal ini dapat dilihat dari 
nilai rata-rata siswa. Bahwa nilai rata-rata kelas eksperimen lebih besar dari pada kelas kontrol. Pada pertemuan pertama kelas kontrol mendapatkan nilai rata-rata 61,81, dan pada pertemuan kedua kelas kontrol mendapatkan nilai rata-rata 57,89. Sedangkan kelas eksperimen pada pertemuan pertama mendapatkan nilai rata-rata 65,29, dan pada pertemuan kedua mendapatkan nilai rata-rata 84,11.

Priyono (2010). Dalam penelitiannya yang berjudul "Upaya meningkatkan hasil belajar IPS melalui strategi peer lesson pada siswa kelas IV SDN Nglahar Kecematan Moyudan Kabupaten Sleman”. Penelitian ini bertujuan meningkatkan hasil belajar IPS menggunakan strategi Peer Lesson pada siswa kelas IV SDN Nglahar Kecematan Moyudan Kabupaten Sleman tahun ajaran 2013/2014. Hasil penelitian ini menunjukkan adanya peningkatan hasil belajar IPS dengan menggunakan srtategi Peer Lesson. Sebelum dilakukan tindakan 8 siswa mencapai ketuntasan $(44,44 \%)$ dan 10 siswa belum mencapai ketuntasan $(55,56 \%)$. Setelah dilakukan tindakan siklus I siswa yang mencapai ketuntasan 11 siswa $(61,11 \%)$ dan belum tuntas 7 siswa $(38,89 \%)$. Setelah tindakan siklus II siswa tuntas belajar 15 siswa $(83,33 \%)$ dan belum tuntas 3 siswa $(16,67 \%)$.

Berdasarkan hasil observasi awal peneliti pada bulan Juli menunjukkan bahwa SMP Negeri 6 Kota Bima adalah sekolah yang masih mendominasi metode ceramah dalam pembelajaran dengan kata lain penyajian materi masih bersifat monoton sehingga peserta didik menjadi bosan karena tidak mendapat kesempatan untuk mengembangkan ide-ide mereka dan tidak diaktifkan dalam proses pembelajaran dan realita lapangan menunjukan bahwa peserta didik tidak memiliki keinginan untuk belajar. Banyak peserta didik merasa jenuh didalam kelas dan mengantuk sehingga tidak mampu memahami dengan baik pelajaran yang disampaikan oleh guru yang mengakibatkan hasil belajar peserta didik masih tergolong rendah, sebagian besar peserta didik memiliki nilai dibawah standar KKM, dimana standar KKM yang telah tetapkan oleh sekolah adalah 75.

Hipotesis yang di ajukan dalam penelitian ini yaitu: Ho : Tidak terdapat pengaruh strategi pembelajaran Peer Lesson terhadap hasil belajar IPA Terpadu siswa kelas VIII SMP Negeri 6 Kota Bima tahun pelajaran 2018/2019. Ha : Terdapat pengaruh strategi pembelajaran Peer Lesson terhadap hasil belajar IPA Terpadu siswa kelas VIII SMP Negeri 6 Kota Bima tahun pelajaran 2018/2019. Sedangkan asumsi penelitian adalah untuk mendapatkan hasil belajar yang maksimal dan memuaskan maka perlu menggunakan strategi pembelajaran Peer Lesson, karena dengan menggunakan strategi pembelajaran Peer Lesson dapat meningkatkan hasil belajar peserta didik. 


\section{METODE PENELITIAN}

Pendekatan yang digunakan dalam penelitian ini adalah Quasi eksperimen. Quasi Experiment adalah jenis eksperimen yang mempunyai kelompok kontrol tetapi tidak dapat berfungsi sepenuhnya untuk mengontrol variabel-variabel luar yang mempengaruhi pelaksanaan eksperimen (Sugiyono, 2013). Sehingga dalam penelitian quasi eksperimen, peneliti memilih dua kelas yaitu satu kelas sebagai kelas eksperimen dan satu kelas sebagai kelas kontrol. Kelas eksperimen diberikan strategi pembelajaran Peer Lesson sedangkan kelas kontrol menggunakan metode ceramah.

Populasi dalam penelitian ini adalah seluruh siswa kelas VIII SMP Negeri 6 Kota Bima tahun pelajaran 2018/2019. Peneliti mengambil 2 kelas yang terdiri dari kelas VIII ${ }^{\mathrm{C}}$ dan $\mathrm{VIII}^{\mathrm{D}}$ yang berjumlah masing-masing kelas 29 orang. Dimana kelas $\mathrm{VIII}^{\mathrm{C}}$ sebagai kelas kontrol dan kelas VIII ${ }^{\mathrm{D}}$ sebagai kelas eksperimen.

Teknik pengambilan sampel dilakukan dengan cara Simple Random Sampling yaitu dengan pengambilan anggota sampel dari setiap populasi yang dilakukan secara acak tanpa memperhatikan strata yang ada dalam populasi itu, sedangkan instrumen yang di gunakan adalah Tes dan lembar observasi. Tes yang digunakan dalam peneltian adalah post-test. Posttest diberikan diakhir pertemuan setelah proses belajar mengajar berlangsung. Post-test diberikan dengan tujuan untuk mengetahui sejauh mana materi yang dapat dikuasai oleh siswa setelah diberi perlakuan. Test yang digunakan dalam post-test berbentuk tes obyektif pilihan ganda dengan jumlah soal 10 nomor, untuk jawaban benar mendapatkan skor 1 dan untuk jawaban salah mendapatkan skor 0. Sedangkan untuk Observasi, Berdasarkan hasil observasi strategi Peer Lesson didapatkan bahwa penerapan strategi ini ternyata sangat berpengaruh terhadap hasil belajar peserta didik, hal ini terlihat dari hasil penilaian dengan menggunakan lembar observasi aktivitas peserta didik selama kegiatan peserta didik berlangsung. Pengamatan ini dilakukan mulai dari kegiatan belajar mengajar berlangsung sampai kegiatan belajar mengajar selesai.

Variabel penelitian adalah obyek penelitian atau sesuatu yang menjadi titik perhatian suatu penelitian. Dalam hal ini menggunakan dua variabel yaitu Variabel Bebas (X) strategi pembelajaran Peer Lesson. Dan Variabel Terikat (Y) hasil belajar siswa.

\section{HASIL DAN PEMBAHASAN}

\section{HASIL}

Setelah peserta didik mendapatkan perlakuan dengan proses pembelajaran dengan metode ceramah untuk kelas kontrol dan metode peer lesson untuk kelas eksperimen, maka dilakukan post- 
test untuk mengetahui kemampuan peserta didik setelah mendapatkan pembelajaran dengan kedua proses tersebut. Dari pelaksanaan post-test tersebut di peroleh hasil berikut:

Tabel 1. Hasil Post-test

\begin{tabular}{lcc}
\hline Kelompok & Kontrol & Eksperimen \\
\hline Minimum & 40 & 40 \\
Maksimum & 80 & 80 \\
Rata-rata & $52,06 \%$ & $69,31 \%$ \\
\hline
\end{tabular}

Berdasarkan hasil tes belajar pada siswa kelas eksperimen memperlihatkan skor hasil belajar dengan uraian selengkapnya pada lampiran dan apabila dikelompokkan dalam lima kategori, maka distribusi frekuensi seperti ditunjukkan pada tabel berikut ini:

Tabel 2. Distribusi Frekuensi data penggunaan strategi pembelajaran Post-test

\begin{tabular}{ccc}
\hline Skor Siswa & Frekuensi & Presentase \% \\
\hline 40 & 1 & 5,7 \\
50 & 3 & 12,3 \\
60 & 8 & 22,4 \\
70 & 2 & 10,3 \\
80 & 15 & 49,3 \\
\hline Total & 29 & 100 \\
\hline
\end{tabular}

Berdasarkan tabel diatas dapat dibuat grafik seperti gambar berikut ini:

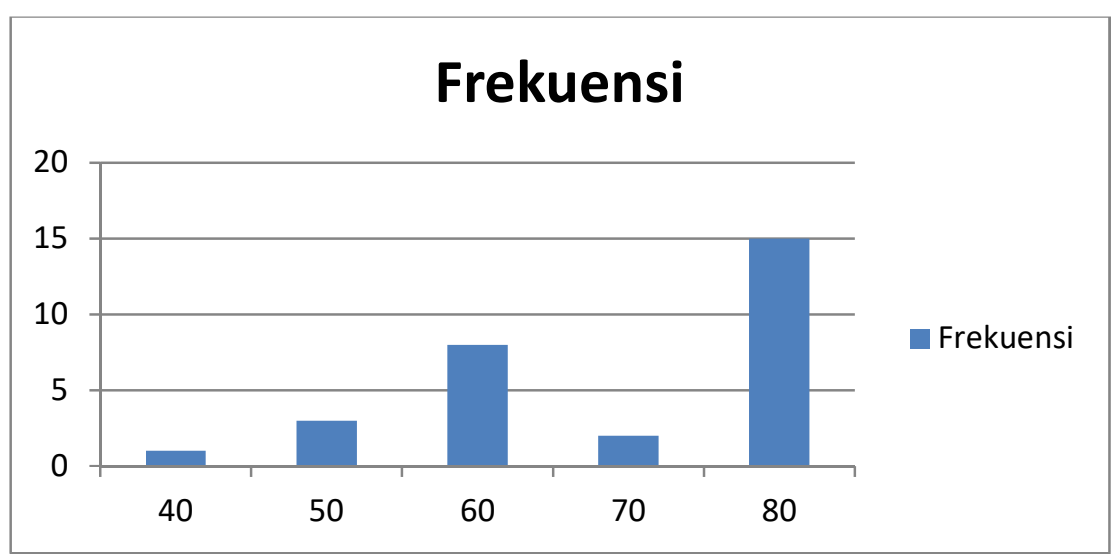

Gambar 1. Persentase hasil belajar siswa dengan menggunakan strategi pembelajaran Peer Lesson

Berdasarkan data diatas menunjukkan bahwa sebagian besar siswa yang diajarkan menggunakan strategi pembelajaran Peer Lesson pada kelas eksperimen yaitu pada skor nilai 40 terdapat 1 orang siswa $(5.7 \%)$, pada skor nilai 50 terdapat 3 orang siswa (12.3\%), pada skor nilai 60 terdapat 8 orang siswa $(22.4 \%)$, pada skor nilai 70 terdapat 2 orang siswa 
(10.3\%) pada skor nilai 80 terdapat 15 orang siswa (49.3\%). Jadi penggunaan strategi pembelajaran Peer Lesson pada kelas eksperimen dapat mempengaruhi hasil belajar.

Berdasarkan hasil tes belajar pada siswa kelas kontrol memperlihatkan skor hasil belajar dengan uraian selengkapnya pada lampiran dan apabila dikelompokkan dalam lima kategori, maka distribusi frekuensi seperti ditunjukkan pada tabel 3 berikut ini:

Tabel 3. Distribusi Frekuensi data penggunaan metode ceramah

\begin{tabular}{ccc}
\hline Skor Siswa & Frekuensi & Presentase \% \\
\hline 40 & 1 & 44,3 \\
50 & 3 & 23,6 \\
60 & 8 & 9,7 \\
70 & 2 & 5,7 \\
80 & 15 & 16,7 \\
\hline Total & 29 & 100 \\
\hline
\end{tabular}

Berdasarkan tabel diatas dapat dibuat grafik seperti gambar berikut ini:

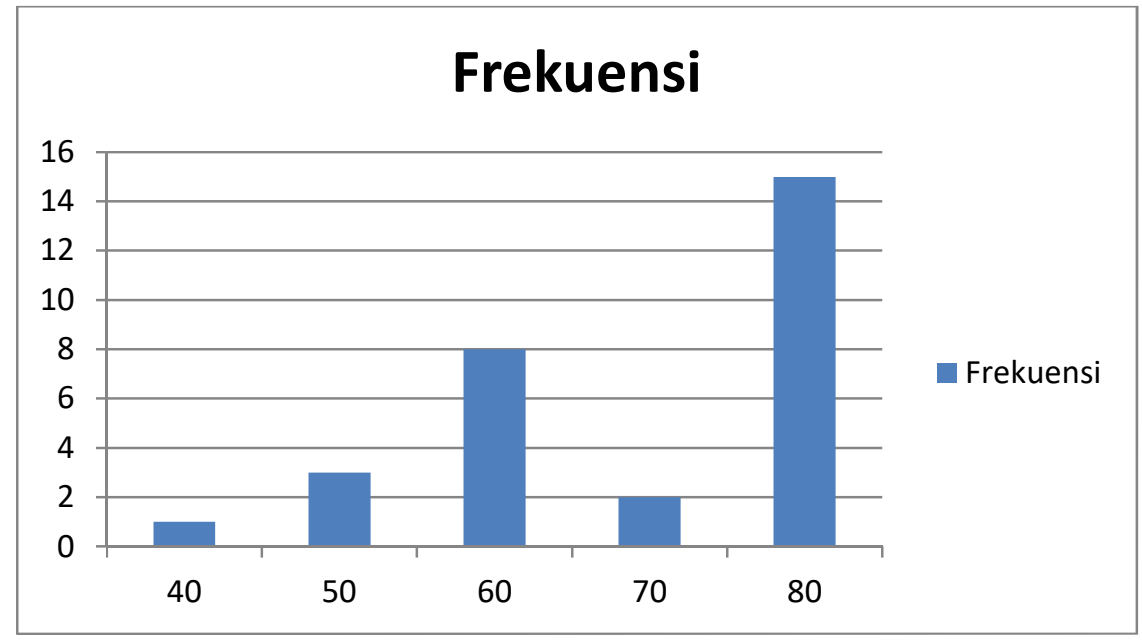

Gambar 2. Persentase hasil belajar siswa menggunakan metode ceramah

\section{PEMBAHASAN}

Berdasarkan hasil analisa dan rata-rata skor nilai yang diberikan dengan menggunakan strategi Peer Lesson diperoleh 69,31, sedangkan rata-rata skor nilai peserta didik yang menggunakan metode ceramah diperoleh 52,06. Hasil penelitian ini menunjukkan bahwa pemebelajaran dengan menggunakan strategi Peer Lesson dapat meningkatkan hasil belajar IPA Terpadu, karena siswa sangat aktif dalam proses pembelajaran dan memperhatikan penjelasan temannya dengan baik ketika proses pembelajaran didalam kelas sedang berlangsung. 
Hasil penelitian ini sesuai dengan teori yang dikemukan oleh (Zaini, 2008) bahwa Strategi pembelajaran Peer Lesson merupakan salah satu strategi pembelajaran aktif yang dirancang untuk mengaktifkan peserta didik sehingga peserta didik tidak belajar secara monoton. Peer Lesson sendiri berasal dari kata Peer dan Lesson. Peer mempunyai arti teman sebaya dan Lesson mempunyai arti pelajaran. Strategi pembelajaran Peer Lesson merupakan salah satu dari pembelajaran model Peer Teaching. Strategi ini mengajarkan peserta didik untuk belajar aktif. Melalui pembelajaran aktif berarti peserta didik mendominasi proses pembelajaran. Strategi pembelajaran Peer Lesson baik digunakan untuk menggairahkan kemauan peserta didik mengajarkan materi kepada temannya. Jika selama ini ada pameo yang mengatakan bahwa metode belajar yang paling baik adalah dengan mengajarkan kepada orang lain. Maka strategi ini akan sangat membantu peserta didik didalam mengajarkan materi kepada teman-teman sekelasnya. Menurut (Silberman, 2008) "Peer Lesson adalah strategi yang mengembangkan kemauan peserta didik mengajarkan materi dalam kelas yang menempatkan seluruh tanggung jawab untuk mengajar para peserta didik sebagai anggota kelas".

Hasil penelitian ini juga relevan dengan hasil penelitian yang dilakukan oleh Priyono dengan judul penelitian "Upaya meningkatkan hasil belajar IPS melalui strategi peer lesson pada siswa kelas IV SDN Nglahar Kecematan Moyudan Kabupaten Sleman" bahwa Penerapan strategi pembelajaran Peer Lesson dapat meningkatkan hasil belajar siswa.

Dengan demikian dapat dikatakan bahwa strategi pembelajaran Peer Lesson memiliki peran yang penting untuk memudahkan siswa mendapatkan hasil belajar yang diharapkan dan membuat peserta didik yang awalnya tidak aktif menjadi lebih aktif dalam proses kegiatan belajar berlangsung.

\section{KESIMPULAN}

Berdasarkan hasil penelitian diketahui bahwa ada pengaruh strategi pembelajaran Peer Lesson terhadap hasil belajar IPA Terpadu siswa kelas VIII SMP Negeri 6 Kota Bima Tahun Pelajaran 2018/2019 yang dapat dilihat dari nilai $t_{\text {hitung }}=4,758>t_{\text {tabel }}=2,003$ dengan demikian hipotesis alternatif (Ha) diterima.

\section{DAFTAR PUSTAKA}

Abdullah, Sani Ridwan. 2013. Inovasi Pembelajaran. Jakarta: Bumi Aksara.

Arikunto S. 2010. Prosedur Penelitian Suatu Pendekatan Praktik. Jakarta: Rineka Cipta. 
Dwijayanti, E. 2016. Penerapan Strategi Pembelajaran Aktif Tipe Peer Lessons Untuk Meningkatkan Aktivitas Dan Hasil Belajar Siswa. Jambi: Jurnal EduFisika

Kasmadi dan Nia. 2014. Panduan Modern Penelitian Kuantitatif. Bandung: Alfabeta.

Musfiqon. 2012. Pengembangan Media dan Sumber Pembelajaran. Jakarta: Prestasi pustaka Publisher.

Priyono. 2010. Upaya meningkatkan hasil belajar IPS melalui strategi peer lesson pada siswa kelas IV SDN Nglahar Kecematan Moyudan Kabupaten Sleman: Universitas Negeri Yogyakarta.

Rusman. 2012. Belajar dan Pembelajaran Berbasis Komputer Mengembangkan Profesionalisme Guru Abad 21. Bandung: Alfabeta.

Silberman, Mel. 2008. Active Learning 101 Strategi Pembelajaran Aktif. Yogyakarta: Pustaka Insan Madani.

Sudijono, A. 2009. Evaluasi Pendidikan. Jakarta: Rajawali Pers.

Sugiyono. 2010. Metode Penelitian Kuantitatif Kualitatif dan R\&D. Bandung: Alfabeta. 2012. Metode Penelitian Kuantitatif Kualitatif dan R\&D. Bandung: Alfabeta. 2013. Metode Penelitian Pendidikan Pendekatan Kuantitatif, Kualittaif, dan R\&D. Bandung: Alfabeta.

Suprijono, A. 2009. Cooperative Learning. Yogyakarta: Pustaka Pelajar.

Veronica, Laelatul Fikriyah. 2013. Efektifitas Strategi Peer Lesson dalam Pembelajaran Bahasa Arab Siswa Kelas VIII MTsN Lab UIN Yogyakarta: UIN Sunan Kalijaga Yogyakarta.

Zaini, H. 2008. Strategi Pembelajaran Aktif. Yogyakarta: CTSD. 